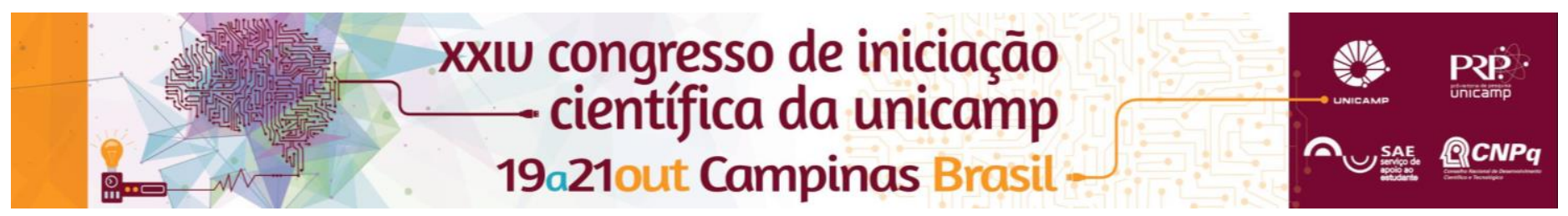

\title{
Dinâmica Urbana no município de São João da Boa Vista (SP): Mercado Imobiliário e Ações Estatais
}

\author{
Charles Serra Tabarin*, Claudete de Castro S. Vitte.
}

\begin{abstract}
Resumo
A pesquisa teve como objetivo principal a caracterização da expansão urbana e imobiliária recente em São João da Boa Vista (SP), observando os principais eixos de expansão, de valorização, as áreas em adensamento e implantação de equipamentos públicos destinados às novas áreas de expansão imobiliária. Essa análise foi baseada na ação dos agentes produtores do espaço urbano e seu reflexo na urbanização, promovendo a segregação socioespacial, reduzindo o direito à cidade para todos e outras adversidades urbanas.
\end{abstract}

Palavras-chave: Geografia Urbana, São João da Boa Vista, Produção do Espaço Urbano.

\section{Introdução}

A expansão urbana vivida nos últimos anos nas cidades médias brasileiras teve como principais fatores 0 aumento no número de condomínios fechados horizontais e, principalmente, na implantação de loteamentos voltados à habitação popular, através do Programa Minha Casa, Minha Vida, do governo federal. A tendência se repete em São João da Boa Vista, onde foram implantados diversos conjuntos habitacionais populares na região Sul da cidade e, inúmeros condomínios fechados horizontais, principalmente na região Leste da mancha urbana.

Dessa forma, o objetivo dessa pesquisa é contribuir com a discussão da dinâmica urbana de São João da Boa Vista (SP), destacando as ações dos agentes produtores do espaço na expansão urbana. Também aprofunda a compreensão da espacialização de fenômenos urbanos intensificados com a ação planejada de agentes como o Estado, os agentes imobiliários, proprietários fundiários e outros atores que interferem na produção do espaço urbano.

\section{Resultados e Discussão}

A metodologia utilizada no projeto envolveu uma revisão bibliográfica sobre a produção do espaço urbano e o papel dos agentes produtores do espaço na formação da cidade; caracterização socioeconômica do município, utilizando dados cedidos pela Prefeitura Municipal e do Censo IBGE 2010, além de observações de campo e análise de notícias; verificação da ação dos agentes produtores do espaço local, recorrendo às fontes já citadas, ao Plano Diretor antigo e sua revisão, além de documentos públicos; e, elaboração de mapas através do uso do software ArcGis 10.

O espaço urbano é concretizado por agentes sociais, cujas ações são complexas, e derivam da dinâmica do capital, das necessidades das relações de produção e dos conflitos de classes ${ }^{1}$. Os principais agentes são: o Estado; proprietários dos meios de produção; proprietários fundiários; promotores imobiliários e os grupos sociais excluídos.

O Estado regulamenta a produção do espaço urbano a partir do Plano Diretor, que vem sendo revisto no município, com base em decisões locacionais, públicas ou privadas, em áreas como transporte, zoneamento, localização dos bens públicos e de moradias. Além disso,

DOI: 10.19146/pibic-2016-50640 promove a reprodução do espaço ao financiar a construção de moradias de interesse social, com o Programa Minha Casa, Minha Vida.

Os promotores imobiliários, agindo em conjunto com os proprietários fundiários são os maiores responsáveis pela expansão urbana da cidade, agindo em duas frentes, sendo elas a construção de habitação social com financiamento estatal e construção de loteamentos residenciais abertos e fechados. Segundo Spósito, os loteamentos fechados podem ser considerados como novos habitats urbanos, "porque rompem com os princípios de unidade e de integração socioespaciais que sempre marcaram a cidade (...)".

Dessa forma, percebe-se que a mancha urbana se caracteriza pela fragmentação, reflexo da formação multitemporal, resultando em uma cidade que agrega loteamentos com níveis de renda diferentes em espaços vizinhos, contudo socialmente segregados por barreiras físicas ${ }^{2}$.

O Ministério Público local começa a agir no município contra a segregação socioespacial e a carência de infraestruturas básicas nos novos loteamentos, embargando condomínios fechados e loteamentos abertos da cidade.

\section{Conclusões}

A dinâmica urbana em São João da Boa Vista ocorre com a produção do espaço baseada na ação de diferentes agentes, a partir do planejamento estatal em consenso com interesses privados, promovendo uma expansão baseada na segregação socioespacial, com a presença infraestruturas desiguais. A sociedade, através da ação da justiça, se contrapõe a essa realidade, buscando soluções com a revisão do Plano Diretor.

\section{Agradecimentos}

Agradecemos ao apoio do Conselho Nacional de Desenvolvimento Científico e Tecnológico (CNPq), a Deus, orientadora Claudete Vitte, família e amigos.

${ }^{1}$ CÔRREA, Roberto L. “O espaço urbano”. Ática: São Paulo, 1989.

${ }^{2}$ SPÓSITO, Maria Encarnação B. "Loteamentos fechados em cidades médias paulistas - Brasil”. In: SPOSITO, Eliseu Savério; SPOSITO, Maria Encarnação; SOBARZO, Oscar (orgs.). Cidades médias: produção do espaço urbano e regional. São Paulo: Expressão Popular, 2006, p. 175-197.

XXIV Congresso de Iniciação Científica da UNICAMP 